\title{
Technology, Sovereignty and Realpolitik
}

\author{
Hermann Hauser
}

\begin{abstract}
This analysis exposes how the current revolution in the digital and biospheres creates threats to national sovereignty in new ways. The view of sovereignty built on military strength is outdated. Sovereignty of a nation is defined as the "supreme authority in a territory", but it is better understood by examining the freedom from one-sided dependencies and military or economic coercion. In the past, sovereignty was mainly associated with military dependency and the resulting coercion by foreign states. This has changed with the rise of technology and its importance to the economy. Dependence on critical technologies can lead to economic coercion by states and large companies which are as effective as the military one. In the future, every nation or group of nations must ask itself three questions: Do we have control over critical technologies? If not, do we have access to critical technologies from a number of independent countries? If still not, do we have guaranteed, unfettered, long-term (more than 5 years) access to monopoly or oligopoly suppliers of a single country (Typically this will be the US or China)? If the answer to all three questions is no, then that nation is open to economic coercion that is no less severe than the military coercion of yesteryear.
\end{abstract}

Keywords Revolution in the digital and biospheres - Threats to national sovereignty - Sovereignty built on military strength - "Supreme authority in a territory" - Rise of technology and its importance to the economy - Dependence on critical technologies $\cdot$ Economic coercion by states $\cdot$ Control over critical technologies $\cdot$ Access to critical technologies

\section{Introduction and Definition}

Sovereignty is defined as the "supreme authority in a territory". But it is best understood by examining the freedom from one-sided dependencies and military or economic coercion. In the past, sovereignty was mainly associated with military dependency and the resulting coercion by foreign states. This has changed with the

H. Hauser ( $ه)$

Amadeus Capital Partners, Cambridge, UK 
rise of technology and its importance to the economy. Dependence on critical technologies can lead to economic coercion by states and large companies which are as effective as the military one.

It became clear during the COVID-19 crisis how dependent the world was on Chinese manufacturing of masks and PPE, while the Trump administration made the world aware that China was dependent on the USA for chip design software and the global dollar-based payment infrastructure.

\section{The 3 Key Questions on Technology Sovereignty}

In the future, every nation or group of nations must ask itself three questions:

1. Do we have control over critical technologies?

2. If not, do we have access to these technologies from a number of independent countries?

3. If still not, do we have guaranteed, unfettered, long term (more than 5 years) access to monopoly or oligopoly suppliers of a single country (Typically this will be the US or China)?

If the answer to all three questions is no, we lay ourselves open to economic coercion that is no less severe than the military coercion of yesteryear.

\section{An Ideal World}

To better understand the situation we are in, let us examine an ideal utopian world. This is where most major nations, or federation of nations (like the EU), enjoy the following characteristics:

1. Every region has most, or all of the critical, technologies and access to most, or all of the relevant, supply chains. Each area can manufacture products based on these technologies and has the software, logistics and payment systems to make it work for their economy, their government and for export.

2. There are open worldwide standards and IP arrangements for each of the technologies to ensure healthy competition between the regions resulting in vibrant global trade between all regions. This creates many dependencies, but they are all symmetric ensuring they do not lead to coercion whereas withholding technology or products from one region would produce a reciprocal action in the opposite direction.

3. There is no dependency on a single region for anything.

The reality is very far from this ideal state as most advanced critical technologies are concentrated in a small number of nations, namely, the US, EU, China, Japan and Korea. 


\section{Analysis Tools}

An excellent report on technology sovereignty (Edler et al. 2020) by the Fraunhofer Gesellschaft, a world leading research institute, helps us with analysis.

Firstly, we need to determine whether a technology is critical. That means determining if a technology is indispensable, now or in the future, and how access to that technology could be threatened by external shocks. These shocks can be natural like the COVID-19 crisis or man-made by states exercising extra-territorial coercion.

Secondly, we need to examine the functional context in which a technology is critical. Is it economic competitiveness, meeting social needs such as healthcare, energy supply, communications infrastructure, transport and logistics, or sovereign tasks like the security of citizens.

Thirdly, we need to define the spatial-political system boundaries, in which technology sovereignty can be achieved.

Fraunhofer lists the following tools and methods to decide whether a region is technologically sovereign:

- The number of patents and percentages of world patents that a region holds in a particular technology sector;

- The number of publications and contributions to world standards of a region, which indicates the degree of autonomy, it has in shaping the future of a specific technology;

- Technology and resource-specific production statistics that enable the identification of the regional availability of relevant resources and production capacities;

- Technology specific export shares which provide information about the international competitiveness of the production of a state or a federation of states.

The following helps us understand the dependencies and access to competencies and resources from other regions.

- International standards, patent pools and open-source repositories which provide information about internationally available technologies that can be used;

- Trade balances grouped and analysed by technology provide information about the dependence of a state or a federation of states on technology-specific imports (resources and components), and their distribution;

- Complexity indices make it possible to estimate the dependence of relevant geographical areas on specific technologies and how these technologies are integrated into local or regional innovation and value chains;

- Analyses of World Trade Organisation (WTO) compliance enable a concrete assessment of the reliability of potential partner nations in specific issues;

- Analyses of the World Bank's World Governance Index, various corruption indices and indices on the form of governance make it possible to assess the basic reliability of potential partner nations. 


\section{Examples of Critical Technologies}

The following examples were chosen to illustrate these issues: $5 \mathrm{G}, 5$ nanometer semiconductor fabs, virus technology and payment systems.

\section{$5.15 G$}

This is a global standard which originated in Europe as Groupe Speciale Mobile (GSM). Setting global standards is one of Europe's strengths as it had to accommodate the requirements of many different European nations in the European Union. The $\mathrm{EU}$ is the only major region in the world that has a significant government structure above the nation state. The EU marshalled this edifice having realised that much is to be gained by giving up a small amount of national sovereignty for the benefit of all EU citizens. Although this has also caused some problems, as Brexit has shown, it is the best working example we have that can guide us towards nations sharing some technology sovereignty for the benefit of mankind as a whole.

To understand any critical technology like $5 \mathrm{G}$ we have to look at standards, fundamental patents, research capabilities, innovation, manufacturing capacity, software, logistics and payment infrastructure.

At present, Chinese companies, especially Huawei and ZTE, account for 33\% of total $5 \mathrm{G}$ patents worldwide, South Korea comprises 27\%, European companies 17\%, and US/North American companies 14\% (Edler et al., 2020). This produces a reasonable Herfindahl Hirschman Index (HHI) value, the accepted measure of supplier concentration, taking into account the number of players and their market share. The lead supplier with the most advanced technology and the largest market share is Huawei.

The US feels threatened by Huawei's dominance and has started a campaign against the company using American dominance in design software for semiconductor chips. As practically all the chips in the world are designed using US software and President Trump could coerce non-US companies as well as TSMC (Taiwanese Semiconductor Manufacturing Company), the main foundry supplier to Huawei, to stop supplying them with state-of-the-art chips. The US also used security concerns to coerce other countries like the UK to stop buying Huawei equipment. This example is an excellent example of how economic coercion is just as effective as military might, but much less controversial.

Imagine the following hypothetical scenario:

\footnotetext{
Vice-Admiral Eugene H. Black III, commander of the US 6th fleet, makes a request of the British Prime Minister and pointed to the positions that his fleet had taken up in the English Channel. In this case, most people in Britain would object to this interpretation of the special relationship.
}

Now let us examine a real situation in 2020: 
Mike Pompeo, the US Secretary of State requested that the UK Prime Minister stop using Huawei $5 \mathrm{G}$ products. Pompeo implied that if the UK did not comply with the ban on Huawei, the US would stop sharing intelligence with the UK. Both parties also understood that the USA controls the payment infrastructure of the City of London. In addition, US software is needed for the design of all UK electronic chips. However, there was no public outcry at this demand from Pompeo. This was despite the fact that the thorough security analysis by GCHQ, the UK's world renowned security organisation had concluded that it was safe to use Huawei products in non-critical parts of 5G infrastructure. Pompeo's coercion was equally blatant, but technological might is less visible to the public than a US aircraft carrier at the mouth of the Thames.

In the past, Britain's dependence on other nations was overlooked because it was believed that supply chains were secure. Also, the USA was considered a friendly, dependable ally. Both these assumptions have been brought into question by recent events.

\subsection{5 nanometer (nm) Semiconductor Fabrication}

The most advanced electronic devices today, including smartphones, $5 \mathrm{G}$ processors, and server chips for data centres all require $5 \mathrm{~nm}$ fabrication. Intel, which used to be the leading semiconductor processor company in the world, has recently fallen behind and there are now only two suppliers capable of delivering $5 \mathrm{~nm}$ chips: Taiwanese Semiconductor Corporation (TSMC) and Samsung in Korea.

This is clearly an unacceptable concentration of suppliers. The US has asked TSMC to build a state-of-the-art factory in Phoenix Arizona, ${ }^{1}$ so they have local access to the latest technology. Samsung is also building fabrication plants in the US. The EUR 672bn Recovery and Resilience Facility of the EU includes EUR 145bn for semiconductor and processor technologies. ${ }^{2}$ China has made it a national priority to develop an independent semiconductor technology and is willing to spend even larger amounts. ${ }^{3}$ However, unless each region develops its own design software, the dependence on the US will remain.

By using the US monopoly on chip design software as a weapon, Trump has caused the rest of the world to scramble for alternatives. As is so often the case with short term populist thinking, the result will be the opposite of what was intended. Both the EU and China will develop their own software to ensure independence from the US and the ability of the US to export their software and use it for economic coercion will disappear.

\footnotetext{
${ }^{1}$ https://www.bloomberg.com/news/articles/2020-11-19/tsmc-wins-approval-from-phoenix-for12-billion-chip-plant.

${ }^{2}$ https://ec.europa.eu/info/business-economy-euro/recovery-coronavirus/recovery-and-resiliencefacility_en.

${ }^{3}$ https://www.brookings.edu/techstream/lagging-but-motivated-the-state-of-chinas-semicondu ctor-industry/.
} 


\subsection{Anti-virus Technology}

The COVID-19 pandemic has shown the world how dependent many nations are on Chinese manufacturing. If COVID-19 had been more deadly, and all transport had to be shut down to stop infections from spreading, most nations would have had to go without masks and PPE. This is a clear dependency that is unacceptable and local manufacturing needs to be set up to prevent this from happening in the future. In this case, the technology involved is not advanced and it should be a straight forward goal to achieve.

When it comes to vaccines themselves, the world has shown amazing ingenuity and resolve to come up with new vaccines in record time. While the first vaccines have come from technology leaders like Germany, the UK, the US, China and Russia, there are now 200 vaccines in development in many different countries. It is unlikely that this will result in dependence, but there is a great deal of controversy of manufacturing capacity, speed of delivery and how to help developing nations cope if they cannot afford to purchase vaccines.

\subsection{International Payment Systems}

The U.S. walked away from the Iran agreement. Europe has not and would like to do some trade with Iran, but they are being bullied by the U.S. Treasury," said Gary Smith, founder of Sovereign Focus, a consultancy based in London. "So, having an alternative payment system that Europe can use without falling foul of the U.S. Treasury is something that probably has some appeal. ${ }^{4}$

Last year, the US State Department put the Hong Kong Chief Executive, Carrie Lam and other senior executives on a list that bars them from accessing the US financial system. Even China's largest state-run banks operating in Hong Kong have had to comply to ensure access with crucial dollar funding. Major lenders with operations in the US, including the Bank of China, China Construction Bank and China Merchants Bank have become cautious on opening new accounts for the officials on the list, including Lam, Bloomberg News reported in August. ${ }^{5}$

These dramatic extraterritorial powers of the US have forced the rest of the world to look for an alternative to the US dollar dominated financial system. Central Bank Digital Currencies (CBDC) are seen as a way to become independent from US control of the financial sector. China has the most advanced CBDC, which has already been rolled out in four Chinese cities and will play an important role in the Belt and Road initiative (BRI). At the same time, Europe is also working on an electronic version of the Euro- the e-Euro.

\footnotetext{
${ }^{4}$ https://www.nasdaq.com/articles/cbdcs-could-challenge-us-dollars-dominance\%3A-deutschebank-2020-09-30.

${ }^{5}$ https://www.bloombergquint.com/global-economics/chinese-banks-move-to-comply-with-u-ssanctions-on-hong-kong.
} 
The former head of the Bank of England, Mark Carnie, proposed Synthetic Hegemonic Currencies (SHC) ${ }^{6}$ at the 2019 Jackson Hole Economic Policy Symposium attended by the heads of the world's major central banks. This proposal by Carnie was as a response to private stable coin initiatives like the Facebook Libra. One of the objectives was to "dampen the domineering influence of the US dollar on global trade". The SHC would consist of a basket of the main trading currencies in the world proportional to the trading volume in a particular currency rather than having the majority of international transactions denominated in dollars despite the US only accounting for $15 \%$ of world trade.

Unfortunately, the US is not alone in using economic coercion to promote its agenda. Australia has also been pushed by China:

China has slapped punitive tariffs on Australian barley, restricted beef imports and begun an anti-dumping inquiry into wine exports. Chinese importers have warned their Australian partners that wine, lobster, timber, sugar, coal and copper would face trade disruption from last Friday, according to verbal briefings delivered by Chinese authorities. (Financial Times 2020)

These powers of economic coercion are no longer wielded by governments alone but are increasingly exercised by technology monopolies, which states have allowed to surreptitiously grow into the behemoths they are today. The list of these quasimonopolies, with powers that often exceed those of the state, has grown frighteningly large and covers many aspects of our daily lives. These include Google, Facebook, Twitter, Netflix and Amazon in the US and the Chinese companies Alibaba, Tencent and Baidu.

There is no alternative to breaking up what are, in reality, monopolies. In the US, control must be returned to the people through their elected government by creating a number of competitive players and curbing the excessive power they accumulate by buying up every successful company vaguely related to their sector.

Thomas Philippon's book The Great Reversal-How America Gave Up on Free Markets (Philippon 2019) documents the decline of anti-trust activities in the US due to the power of lobbying in the US politics. This has allowed some of these companies to become de facto monopolies.

The recent activity in China against ANT, owner of Alipay and affiliate of Alibaba Group, is a good example of state intervention as ANT became so large that it was a potential threat to the stability of the entire financial system in China.

\footnotetext{
${ }^{6} \mathrm{https}: / /$ www.bankofengland.co.uk/-/media/boe/files/speech/2019/the-growing-challenges-formonetary-policy-speech-by-mark-carney.pdf.
} 


\section{Territories with Technology Sovereignty}

I would now like to address the issue of how big a territory has to be to enjoy technological sovereignty.

Let us start with a household. A typical family has sovereignty over their home. They can decide when and what to drink and eat, when to turn on the lights or the vacuum cleaner and what to watch on TV and when to use the Internet and what websites to visit. Or do they?

For most people in the world, drinking requires a water supply and food comes from the supermarket, as $50 \%$ of the world's population now lives in cities. Electricity is delivered by the power company through power lines and the Internet needs telephone lines or mobile infrastructure connections. From this perspective, a household's sovereignty is actually very limited and all but the most determined hermits have decided to share their sovereignty over water, food, electricity and the Internet with other people in their village or city. As they have to pay for all these goods, they are also dependent on a national payment infrastructure.

Can cities be sovereign? Many cities have their own water supply, but depend on national supermarket chains and their logistics for the food supply. Electricity is often generated locally, but in order to ensure the supply is not disrupted, they are often linked to a national power grid. The need of people to communicate and travel outside individual cities, there are also national telecoms and transport infrastructures that are based on approved standards.

So, can nations be sovereign? This is where technology makes a big difference. Most developed nations have managed to create their own water production systems and power networks, and many even produce a significant portion of their food supply.

But the latest critical technologies like 5G, $5 \mathrm{~nm}$ semiconductors, global payment infrastructures etc. are not available to most nations. The key question then becomes which territories have the ability to be technologically sovereign in ALL critical technologies. The obvious answer is that there are only three such regions in the world: the US, the EU and China. This poses a dilemma for nations outside these three blocks as they are dependent on one of the three for at least some of these technologies, which are critical for the functioning of their economy and government. This creates dependence that can lead to economic coercion, which is precisely what happened in the UK with $5 \mathrm{G}$.

The only stable long-term solution is to try and get closer to the utopian vision of technology sovereignty by sharing advanced technologies amongst regions on a reciprocal basis. This strategy is the exact opposite of the "America First" concept. We should help China and others to gain access to $5 \mathrm{~nm}$ semiconductor technology in exchange for building factories, say in Europe for the European market and share jointly developed future IP with partners. The principle of reciprocity is the key enabler of this strategy. This worked well for the Japanese car industry in Europe. It is only through mutual dependence that we can achieve a stable long-term state in technology sovereignty. This is particularly important for new technologies, which 
will be critical to the proper functioning of our economies and governments in the next decade or two.

These new technologies include: AI and machine learning, quantum computing, synthetic technology, and blockchain technologies. It is important that we again set global standards in these fields and promote an open research community to share in the latest breakthroughs and then make sure that new one-sided dependencies are not created by either excluding nations from certain technologies or allowing overbearing tech companies to appear and monopolise a particular sector.

Globalisation and the division of labour across the world is clearly beneficial to all but as COVID-19 has shown supply chains can be disrupted. Building resilience into the system is a key requirement for the adoption of these powerful new technologies.

\section{Conclusion}

Technology sovereignty has become a dominant issue for the coming decade. The absence of such sovereignty can lead to one-sided technological dependencies which in turn can lead to economic coercion. In order to avoid a new era of economic colonialisation based not on military occupation, but on technological dependencies, we establish global technical standards and a fair exchange of new technologies through licensing and sharing of manufacturing knowhow that is reciprocal. This will avoid one-sided dependencies and the stresses caused by trade wars.

\section{References}

Edler J et al (2020) Technology sovereignty. Fraunhofer Gesellschaft

Financial Times (2020) https://www.ft.com/content/b764e4c9-cc38-43b6-848c-dba0cbc6475a. Accessed 11 Nov 2020

Philippon T (2019) The great reversal—how America gave up on free markets. Harvard University Press

Hermann Hauser has contributed to the translation of science into business for over thirty years. He has successfully developed and financed over 100 high-tech companies. These include Acorn Computers in 1978 and ARM Holdings in 1990. He went on to co-found Amadeus Capital Partners in 1997. As the author of a 2010 influential report, he called for the UK government's investment in a network of technology and innovation centres. This led to the creation of 'Catapult' Centres. He is a Fellow of the Institute of Physics and of the Royal Academy of Engineering and an Honorary Fellow of King's College, Cambridge. He is also Vice-Chair of the European Innovation Council. 
Open Access This chapter is licensed under the terms of the Creative Commons AttributionNonCommercial-NoDerivatives 4.0 International License (http://creativecommons.org/licenses/bync-nd/4.0/), which permits any noncommercial use, sharing, distribution and reproduction in any medium or format, as long as you give appropriate credit to the original author(s) and the source, provide a link to the Creative Commons license and indicate if you modified the licensed material. You do not have permission under this license to share adapted material derived from this chapter or parts of it.

The images or other third party material in this chapter are included in the chapter's Creative Commons license, unless indicated otherwise in a credit line to the material. If material is not included in the chapter's Creative Commons license and your intended use is not permitted by statutory regulation or exceeds the permitted use, you will need to obtain permission directly from the copyright holder.

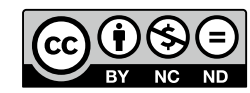

